\title{
FOREST NURSERY SCHOOL - NEW POSSIBILITIES FOR DEVELOPMENT OF CHILDREN KINDERGARTEN
}

\section{Luděk KVAPIL}

\begin{abstract}
The paper relies on forest pedagogy and deals with the education of children in kindergarten LMS.
\end{abstract}

Key words: Forestry forestry education, forest nursery, environmental education, the environment, practical activities.

\section{LESNÍ MATEŘSKÉ ŠKOLY - NOVÉ MOŽNOSTI ROZVOJE DĚTÍ MŠ}

Resumé: Příspěvek se opírá o lesní pedagogiku a zabývá se vzdělávání dětí MŠ v LMŠ.

Klíčová slova: lesní pedagogika, lesní mateřská škola, environmentální vzdělávání, životní prostředí, praktické činnosti.

\section{1 Úvod}

Článek navazuje na lesní pedagogiku a specifikuje lesní mateřskou školu jako jednu z možností vzdělávání dětí MŠ. V dnešní době snad žádné dítě netráví tolik času v př́rodě, kolik by potřebovalo ve zdravém a volném kontaktu s prírodou a jejím prostředím. Tento jev můžeme přičítat malému množství vhodného prostředí $\mathrm{v}$ okolí bydliště, a taktéž doprovodu dospělého průvodce (rodiče apd.). Absence prírodního prostředí má mnoho negativních dopadů na komplexní rozvoj jedince (duševní a tělesný vývoj), odolnost vůči nemocem, špatný rozvoj jemné motoriky a manuální zručnosti. Výzkumy prokázaly, že príčinou je nadměrná organizovanost zdělávání a zábavy $\mathrm{v}$ interiérech, at' už jde o školní, domácí nebo volnočasových prostor. Ministerstvo životního prostředí vydalo v roce 2005 publikaci „Děti aby byly a žily“, v niž se kolektiv autorů zamýšlí nad fenoménem dnešní doby - odcizovaní se dětí prŕŕrodě. Autoři se zaměřuji taktéž na prínosy kontaktů dětí s přírodním prostředím. PhDr. Helena Vostradovská a Mgr. Hana Klonfarova zmiňuji, jak je důležité, aby se dětem dostávalo dostatku pohybu v př́rodním prostředí, seznamovaly se $\mathrm{s}$ př́rodou, která jeobklopuje a zároveň se jim vtiskávala důležitost a nezastupitelnost př́rody spolu s nutnosti a ohleduplnosti k ní, a to od nejútlejšího věku. Přírodu by měly děti poznávat prímým kontaktem, nikoliv zprostředkovaně, a to $\mathrm{v}$ doprovodu rodiče nebo jiné blízké osoby. Vlastním objevitelstvím, nejen poučováním. Pohyb v př́rodě by pro děti měl být samozřejmostí, nikoliv vzácnou př́ležitostí $(1, \mathrm{~s}$. 90).

\section{Lesní pedagogika}

Lesní pedagogika je jedna $\mathrm{z}$ metod lesnické a enviromentální osvěty, zabývající se podáváním pravdivých informací o lese a hospodaření v něm, zábavnou formou, prostřednictvím lesního pedagoga. Důraz je kladen na tzv.,, záźitkové poznání lesa,,.. kdy se účastníci aktivit lesní pedagogiky učí vnímat les všemi smysly, čímž u nich dochází $k$ přirozenému a snadnému zaangažování (2). Lesní pedagogika je zaměřena zvláště na žáky mateřských, základních a středních škol. Tato forma vzdělávání se realizuje formou exkurzí krátkodobých $(4-8$ vyučovacích hodin) nebo exkurzí dlouhodobých (vícedenních), kde školní učebnu nahrazuje lesní prostředí a garantuje ji lesní pedagog.

\section{Lesní mateřské školy LMŠ}

Předškolní vzdělávání podporuje rozvoj osobnosti dítěte předškolního věku. Podílí se na jeho zdravém, citovém, rozumovém a tělesném rozvoji, na osvojení základních pravidel chování, základních životních hodnot a mezilidských vztahů. Předškolní vzdělávání vytváří základní předpoklady pro pokračování ve vzdělávání.

Mateřské školy se povinně řídí od 1.9. 2007 Rámcovým vzdělávacím programem. Tento dokument ukládá předškolním pedagogům sledovat především tři rámcové cíle:

- Rozvíjení dítěte, jeho učení a poznání. 
- Osvojeni základů hodnot, na nichž je založena naše společnost.

- Získání osobní samostatnosti a schopnosti projevovat se jako samostatná osobnost působící na své okolí (3, s. 11).

Rámcový vzdělávací program umožňuje mateřským školám využívat různých metod i forem vzdělávání, přizpůsobovat vzdělávání konkrétním regionálním i místním podmínkám, možnostem a potřebám. Vytváří prostor pro rozvoj různých programů a koncepcí i pro individuální profilaci každé mateřské školy.

Lesní mateřská škola je formou předškolního zařízení, $\mathrm{v}$ jehož programu se většina aktivit odehrává venku, děti si hrají a učí se za každého počasí $\mathrm{v}$ lese, $\mathrm{v}$ krajině, $\mathrm{v}$ prostředí, které bylo po staletí pro vývoj dítěte pririrozeným $(4, \mathrm{~s} .8)$. Toto prostředí umožňuje všestranný rozvoj dítěte:

- Osobní zkušenosti a zážitky, spolupráce, komunikativní dovednosti

- Rozvoj pozorovacích schopností, jemné motoriky, řeči

- Vnímání sama sebe, samostatnost

- Školní připravenost

\section{Historie LMŠ ve světě}

Dánsko 1954 - (Ella Flatau) občanská iniciativa sdružující př́znivce této myšlenky, založena historicky první LMŠ. Dnes je tento způsob předškolní výchovy velmi rozšířen, a má již dlouhodobou tradici ve skandinávských zemích.

Švédsko - existence pod označením "Venku za každého počasí" kolem stovky mateřských škol (5).

Německo 1968 - vznik první lesní MŠ ve Wiesbadenu (dodnes, nezávislá na školské správě). LMŠ je již zařazena do systému předškolního vzdělávání, má oporu v legislativě, což znamená i oporu finanční ze strany státu.

LMŠ existuji také ve Švýcarsku, v Kanadě. V současné době nachází tato myšlenka své prŕznivce i v Japonsku.

\section{Historie v ČR}

Liberec 2007 (Linda Kubale), založena tzv. „zelená školka“.

Praze 2009 (občanské sdruženi Ekodomov), založen dětsky klub „Šárynka“ (částečný provoz).
Nouzov 2009 (Radka Jensen Vaculíkova), založen „dopolední klub“ (občanské sdruženi Za sebevědomé Tišnovsko.

2010 (prosinec) vznik Asociace lesních mateřských škol.

Významným př́nosem je iniciativa $\mathrm{PhDr}$. Terezy Vošahlíkové, která usiluje o ukotveni pedagogického konceptu LMS̆ $\mathrm{v}$ současné legislativě ČR.

Významným krokem je ministerstvem školství povolen experimentální projekt integrované lesní mateřské školy Vesniček $\mathrm{v}$ Praze při Mateřské škole Semínko.

LMŠ jsou specifické svými charakterickými znaky:

- Prostředím

- Oblečení a vybavení

- Zázemí

- Hygiena

- Stravování

- Pedagogické vedení

- Spolupráce s rodiči

\section{Legislativa}

Jelikož LMŠ u nás nesplňují řadu podmínek pro zařazení do rejstř́iku škol, nemohou se ani nazývat mateřskými školami, a od státu nedostávají žádné dotace. Zřizovatelem může být nezisková organizace, občanské sdruženi či fyzická osoba s živností. Jedná se pak nejčastěji o dětské kluby či rodinná centra. Takto se na ně nevztahují vyhlášky o počtu pedagogických pracovníků, hygieně nebo stravování. Na jednu stranu dává těmto klubům jistou volnost, zároveň jsou tím však připraveny o možnost uznání jakožto plnohodnotného vzdělávacího zařízení a zůstávají paradoxně drahou alternativou po boku dalších soukromých mateřských škol vyznačujících se obvykle luxusním zázemím a finančně nákladným programem. Stejná situace byla před více než deseti lety v Německu. Od jejich uznání v roce 1996 a možnosti registrace, jakožto předškolního zařízení, počet lesních mateřských škol v Německu stále narůstá. Od září 2010 MŠMT ČR povolilo pokusné ověřování provozu integrované lesní mateřské školy Lesníček, který tímto může nést označení „,mateřská škola“. Pokusné ověřovaní potrvá dva roky. Činnost lesní školky Lesníček průběžně sleduje MŠMT ČR. Na základě výsledků 
ověřování (resp. pokud se tato forma osvědčí) by měl být zahájen legislativní proces novelizace právních předpisů, kterou by bylo umožněno integrování LMŠ do provozu běžné mateřské školy.

V prosinci 2010 vznikla Asociace lesních mateřských škol (ALMŠ), sdružující jíž existující iniciativy inspirované myšlenkou LMŠ. ALMŠ nabízí pomoc těm, kdo mají o tuto formu předškolní výchovy zájem, sdílením zkušeností o fungování programu lesních MŠ, poradenskou a osvětovou činností. Připravuje podklady pro legislativní změny, jejichž cílem je uznání lesní MŠ jako plnohodnotné alternativy ke klasické mateřské škole. $\mathrm{V}$ této oblasti navázala na činnost pracovní skupiny pro kontakt děti $\mathrm{s}$ př́rodou na Ministerstvu životního prostředí. Momentálně se čeká, jak se osvědčí prvotní provoz integrované lesní mateřské školy Lesníček $\mathrm{v}$ českých podmínkách. $\mathrm{Na}$ základě výsledků, tohoto pokusného ověřování, jsou ochotni připravit úpravy legislativy.

\section{Závěr}

Zdravý vývoj dítěte je prvořadým úkolem institucionálního vzdělávání v ČR. Rozvoj komunikativních, motorických a jiných dovedností, lze dosahovat různými způsoby. Vždy je třeba hledat taková řešení, která budou v souladu se vzdělávacími cíli a nabídnou nám nové způsoby jejich dosahování. Jednou z těchto možností jsou právě LMŠ, které by v budoucnu mohly vyplňovat prázdná místa v kontaktu dětí Olomouc, ČR, tel. 00420585635807 , e-mail: ludek.kvapil@upol.cz $\mathrm{s}$ př́rodou, navázat tak na přirozenou formu jejich rozvoje.

\section{Literatura}

[1] KOLEKTIV AUTORŮ, Děti, aby byly a žily. Praha: Ministerstvo životního prostředí, 2005, 96 s. ISBN 80-7212-382-3.

[2] JANU M., KVAPIL L. Lesní pedagogika a její začlenění do obecně technických předmětů na PdF UP v Olomouci. In Trendy technického vzdělávání 2011. Olomouc: UP, 2011, s. ISBN 978-80-87244-09-0.

[3] Rámcový vzdělávací program pro předškolní vzdélávání. Praha: TAURIS, 2006, s. 11

[4] Věstník ministerstva školství, mládeže a tělovýchovy České republiky, srpen 2010, Praha: Ministerstvo školství, mládeže a tělovýchovy ČR 2010, s. 8.

[5] VOŠAHLIKOVA, Tereza. Lesni mateřská škola - kořeny. Metodicky portál [online]. 19. 08. 2009a. [cit. 21. března 2011]. ISSN 18024785 .

Lektoroval: PhDr. Vlasta Hrdličková, Ph.D.

Luděk Kvapil, Mgr., Ph.D.,

Katedra technické a informační výchovy, Pedagogická fakulta UP,

Žižkovo nám. 5, 77140

tel. 00420585635806 ,

Www pracoviště: www.kteiv.upol.cz 